\title{
A busca pelo sentido da vida As relações como chave de integração na esteira teológica de Leonardo Boff
}

\author{
Orientador: Joel Portella Amado \\ Doutoranda: Rita de Cassia Rosada Lemos \\ Área de Concentração: Teologia Sistemático-Pastoral \\ Linha de Pesquisa: Religião e Modernidade
}

A busca pelo sentido da vida é a interrogação existencial do ser humano. A pesquisa entende ser esta uma sua tarefa essencial, que implica dar significação a uma rede de relações conectada, aberta e em evolução. Na pós-modernidade, a vida tem sido subordinada às coisas, relegada a segundo plano, e pior, simplesmente denegada. O contexto atual é de uma crise fragmentadora e desperdício da abundância de vida, na qual proliferam "promessas" de vida, oriundas de uma visão como relativista e descartável. No entanto, é notável que o ser humano em seu dinamismo interno afirma um a priori de sentido endógeno, uma exigência maior de sentido, que perpassa todas suas relações. A concepção de vida na teologia de Leonardo Boff convida a ver a vida na esteira de um permanente inter-retro-relacionamento, tendo sua origem na inter-relação do mistério do Deus-Trino. Sua concepção é nutrida pelo cuidado, ternura e esperança com respeito à vida. No contexto pós-moderno em que o logos-razão se apresenta como a única via geradora de sentido da existência, a busca pelo sentido da vida supõe uma concepção que não apenas se lhe contraponha, mas questione a coisificação da vida e seu encerramento em si. Esta tarefa toma uma forma específica na qual são fundamentais o resgate e a humanização da vida. Há que se resgatar e proclamar a palavra primeira: "Vida" (Gn 1,1ss), confirmada na vinda do Filho: "Alegra-te" (Lc 1,28) que se faz encontro comunicante na história e a transcende em amor e cuidado de vida.

Palavras-chave: Vida. Relação. Sentido da Vida. 